\title{
Diagnosa Vibrio cholerae Dengan Metode Kultur Dan PCR Pada Sampel Sumber Air Minum
}

\author{
DESI YUSNITA ${ }^{1}$, VISENSIUS KRISDIANILO² \\ Institut Kesehatan Medistra Lubuk Pakam \\ Jl. Sudirman No.38 Lubuk Pakam Pekan, Deli Serdang, Sumatera Utara \\ e-mail :desiyusnitaa54@gmail.com \\ DOI : https://doi.org/10.35451/jfm.v4i1.669
}

\begin{abstract}
Acute diarrhea due to infection can be caused by a bacterial, viral or parasitic infection. One of the bacteria that causes diarrhea is Vibrio cholerae and usually the diarrhea caused is called cholera diarrhea. Cholera diarrhea is caused by enterotoxins produced by $V$. cholerae bacteria and forms colonies inside the small intestine. Symptoms include vomiting, defecation such as large amounts of rice water resulting in dehydration, electrolyte loss and increased blood acidity. In severe cases, the sufferer continuously defecates accompanied by vomiting, so that the sufferer will lose fluids and electrolytes quickly from the gastrointestinal tract. This leads to a rationing of metabolic acidity and when left untreated can lead to death. $V$. cholerae bacteria are not invasive, do not enter the bloodstream but remain in the intestinal tract. At the time of infection through contaminated food and beverages ingested, then after passing through the stomach acid defense $\mathrm{V}$. cholerae produces two virulence factors that cause cholera, namely coregulated pilus toxin (TCP) and cholera toxin (CT). The existence of specific enterotoxin cholera only found in $V$. cholerae pathogens can be targeted in laboratory tests for the diagnosis of pathogenic $V$. cholerae bacteria using biomolecular techniques such as polymerase chain reaction (PCR) methods. From the results of the examination of drinking water samples at the drinking water depot around the bottom of the pakam, obtained the results of the PCR examination confirmed by electrophorensis is $302 \mathrm{bp}$, which means that in the sample there are bacteria that are identic with Vibrio cholera.
\end{abstract}

Keywords : Vibrio cholera, PCR 


\section{LATAR BELAKANG}

Diare akut masih menjadi permasalahan bagi sebaian masyarakat di Negara berkembang. Terdapat beberapa mikroorganisme yang dapat menyebabkan diare salah satunya Vibrio cholera, penyakit yang ditimbulkan oleh bakteri ini dikenal dengan diare kolera. Diare kolera timbul karena bakteri tersebut berkembang dalam usus kecil dan juga memproduksi enterotoksin. Akibat yang ditimbulkan dari adanya enterotoksin dalam tubuh ialah timbul muntah, serta buang air besar dengan jumlah yang banyak dan berwarna seperti air cucian beras, bila munta dan diare dalam waktu yang lama mengakibatkan naiknya keasaman dan akan kehilangan banyak elektrolit dalam tubuh. Bila keadaan ini makain parah dapat menyebabkan kematian (Sumarsono, 1996 dan Pelezar, 2005).

Vibrio cholerae secara morfologi termasuk kedalam bakteri gram negative berbentuk batang bengkon seperti koma, ukuran bakteri ini 0,5 $\mu \mathrm{m}$ $x$ 1,5 sampai $3,0 \mu \mathrm{m}$, Vibrio cholerae hidup secara aerob dan juga anaerob fakultatif, bakteri ini dapat bergerak karena terdapat flagel monotrik, bakteri ini dapat tumbuh pada suhu $18-37^{\circ} \mathrm{C}$, pada biakan yang sudah lama bakteri ini dapat berubah ke bentuk batang lurus dan juga bakteri ini tidak dapat menghasilkan spora (Matson, 2007).
Vibrio cholerae terdapat hidup di usus dan tidak dapat masuk kedalam aliran (Lindmark, 2009). Toxin coregulated pilus (TCP) dan cholera toxin (CT) dihasilkan dari kontaminasi Vibrio cholera yang maasuk melalui makanan ataupun minuman yang kemudian dapat melewati asam lambung dalam tubuh (Chauduri, 2009 dan Walia, 1999). cholera enterotoksin yang hanya ada pada V. cholerae pathogen, menjadi target identifikasi dalam pemeriksaan laboratorium untuk mengidentifikasi bakteri $V$. cholerae pathogen, teknik yang digunakan untuk identifikasi tersebut adalah metode polymerase chain reaction (PCR) (Chomvarin, 2007 dan Marashi, 2013).

\section{METODE}

\section{Pembiakan Bakteri}

Sampel air minum pada depot disekitar lubuk pakam diambil masing masing $50 \mathrm{ml}$ kemuadian dihomogenkan, selanjutnya sampel ditanam terlebih dahulu pada media pembenihan berisi alkaline peptone water (APW) lalu diinkubasi pada suhu $37^{\circ} \mathrm{C}$ selama $18-24$ jam. Hasil pembenihan disubkultur ke media thiosulfate-citrate-bile-sucrose (TCBS) lalu diinkubasikan pada suhu $37^{\circ} \mathrm{C}$ selama 18-24 jam.

Uji Biokimia

Biakan bakteri hasil kultur pada media TCBS di tanam pada media 
biokimia seperti uji Kligler Iron Agar (KIA), uji oksidase, uji pertumbuhan dengan tidak menambahkan $\mathrm{NaCl}$, uji Sucrose Semi Solid(SSS), uji Motility Indole Ornithine (MIO), uji dekarboksilasi (lysine, arginine, ornithine ), serta uji maltose, dan arabinose.

Untuk Identifikasi molekuler secara Polymerase Chain Reaction (PCR) menggunakan kit Invitrogen. Selanjutnya Primer akan diencerkan sesuai dengan instruksi pada kit dalam tube master. Kemudian melalui tahapan predenaturasi pada suhu $94^{\circ} \mathrm{C}$ selama 5 menit, untuk proses denaturasi berlangsung pada suhu $94^{\circ} \mathrm{C}$ selama 1 menit, proses annealing (pengikatan) berlangsung pada $55^{\circ} \mathrm{C}$ selama 1 Menit, kemudian proses extention (pemanjangan) berlangsung pada suhu $72^{\circ} \mathrm{C}$ selama 1 Menit, dan proses elongation (pemanjangan akhir) berlangsung pada suhu $72^{\circ} \mathrm{C}$ selama 7 menit. Siklus pada Proses PCR terjadi sebanyak 35 siklus. Setelah proses pemanjangan rantai kemudian proses selanjutnya identifikasi secara elektroforeses dengan terlebih dahulu menyiapkan Gel agarosa 2\% kemudian diletakan pada alat elektroforesis. Proses selanjutnya mengambil sampel sampel sebanyak $9 \mu \mathrm{L}$ yang sudah homogen dengan blue juice sebanyak 1 $\mu \mathrm{L}$ kemudian dimasukkan ke dalam well (sumur). Proses deteksi secara Elektroforesa dilakukan dengan tegangan 100 volt dan berlangsung sekitar 45 menit. Setelah proses selesai gel kkemudian dimasukan ke alat pengamat DNA (Gel Doc) dan diamati dengan lampu UV. Hasil yang didapatkan selanjutnya akan dibandingkan dengan pita standar Vibrio cholera.

\section{HASIL DAN PEMBAHASAN}

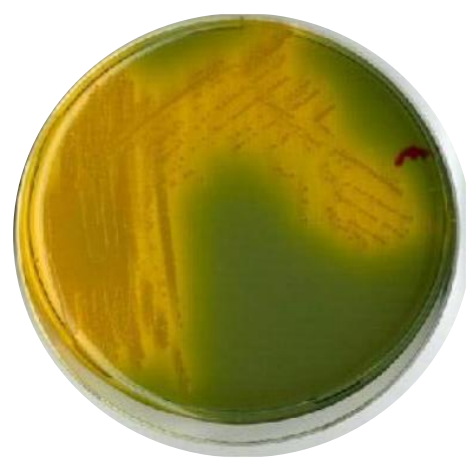

Gambar 1. Hasil penanaman sampel pada media TCBS

Hasil identifikasi sampel pada air minum didapat morfologi pada media TCBS adalah permukaan halus, agak datar, bagian tengah koloni buram dan bagian pinggir koloni terang serta berwarna kuning, hasil dapat dilihat pada gambar 1

Tabel 1. Hasil Uji Biokimia

\begin{tabular}{lcc}
\hline & UJI BIOKIMIA & HASIL \\
\hline OKSIDASE & +
\end{tabular}


Jurnal Farmasi, e-ISSN: 2655-0814

Vol. 4 No.1 Edisi Mei-Oktober 2021

http://ejournal.medistra.ac.id/index.php/JFM

Received: 26 April 2021 :: Accepted: 21 Juni 2021 :: Published: 31 Oktober 2021

\begin{tabular}{lc}
\hline PERTUMBUHAN TANPA PENAMBAHAN & + \\
$\mathrm{NaCl}$ & Alkali/ Asam \\
Klingler Iron Agar (KIA) & +++ \\
Motility Indole Ornithine (MIO) & + \\
Sucrose Semi Solid (SSS) & + \\
Lysine & - \\
Arginine & + \\
Ornithine & + \\
Maltose & - \\
arabinose & \\
\hline
\end{tabular}

Hasil uji biokimia dari isolate hasil kultur dari sampel air minum pada media uji oksidase, pertumbuhan tanpa penambahan $\mathrm{NaCl}$, KIA (Kligler Iron Agar), MIO (Motility Indole Ornithine), SSS (Sucrose Semi Solid), lysine, arginine, ornithine, maltose, dan arabinose, sebagian besar hasilnya positif kecuali pada uji arginine dan arabinose yang menunjukan hasil negative.

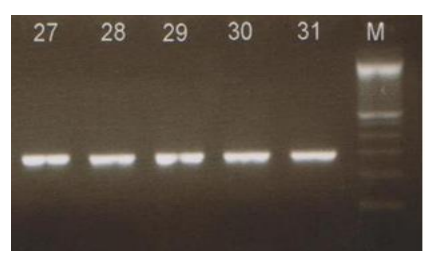

Gambar 2. Hasil elektroforensis sampel bakteri

Hasil uji PCR Pada sampel yang di deteksi dengan elektroforensis menggunakan sinar UV, didapatkan panjang pita pasangan basa DNA yang nantinya dibandingkan dengan pita standard, untuk hasil identifikasi didapatkan pita sepanjang 302 bp, sedangkan untuk panjang pita standar V. cholera sekitar 302 bp, yang berarti hasil identifikasi pada sampel bakteri tersebut identic dengan bakteri Vibrio cholera.

Polymerase Chain Reaction (PCR) menjadi metode baku dalam proses amplifikasi urutan basa DNA tertentu (selektif). Polymerase Chain Reaction (PCR) digunakan pertama kali oleh Kary Mullis di tahun 1987. Polymerase Chain Reaction (PCR) dapat menggandakan jumlah urutan nukleotida atau urutan basa tertentu secara in vitro (didalam tabung). Proses penggandaan urutan basa tersebut terjadi dengan adanya reaksi polimerisasi secara berulang-ulang dan berantai selama beberapa siklus, dalam setiap reaksi polimerisasi memerlukan untai DNA yang nantinya digunakan sebagai template (cetakan) (Sachse, 2010).

Keunggulan diagnosis DNA menggunakan metode PCR pada identifikasi bakteri $V$. cholerae yaitu 
proses yang dibutuhkan relative cepat dan metode ini memiliki sensitifitas dan spesifisitas yang tinggi jika dibandingkan dengan metode kultur (pembiakan) yang menjadi metode baku emas (gold standard) pada identifikasi bakteri (Kaper,1995 dan Rosilawati, 2002).

\section{KESIMPULAN}

Dari hasil pemeriksaan sampel air minum pada depot air minum disekitar lubuk pakam, didapatkan hasil dari pemeriksaan PCR yang dikonfirmasi dengan elektroforensis adalah 302 bp, yang berarti pada sampel tersebut terdapat bakteri yang identic dengan Vibrio cholera.

\section{DAFTAR PUSTAKA}

Chomvarin C, Namwat W, Wongwajana $S$, Alam M, Thaew-Nonngiew K, Sinchaturus A, Engchanil C. Application of duplex-PCR in rapid and reliable detection of toxigenic Vibrio cholerae in water samples in Thailand. J. Gen. Appl. Microbiol. 2007; 53: 229 237.

Kaper JB, Morris JG, Levine MM. Cholera. Clinical Microbiology Reviews. Clin. Microbiol. Rev. 1995; $8(1): 48$.

Lindmark Barbro. Modulators of Vibrio cholerae Predator iInteraction and Virulence. Sweden: Department of
Molecular Biology Umea University; 2009.

Marashi SMA, Rajabnia R, Fooladi AAI, Hojati Z. Determination of ctxAB Expression in Vibrio cholerae Classical and ElTor Strains using Real Time PCR. Int J Mol Cell Med. 2013;2: 9-13.

Matson JS, Withey JH, DiRita VJ. Regulatory Networks Controlling Vibrio cholerae Virulence Gene Expression. Infection and Immunity. 2007; 75(12): 5542士49.

Pelczar J.M. Dasar \pm Dasar Mikrobiologi. Jakarta: Universitas Indonesia, 2005.

Rosilawati ML, Sudarmono P, Ibrahim F. Sensitivitas metode PCR (Polymerase chain reaction) dalam mendekteksi isolatklinis Mycobacterium tuberculosis. J Kedokteran Trisakti. 2002;.21(1)

Sachse K, Nat R, Frey J. PCR detection of microbial pathogens. Humana Press; 2010.

Soemarsono H. Kolera: dalam Buku Ajar Ilmu Penyakit Dalam. Jakarta: Balai Penerbit FKUI, 1996. p. 443 